\title{
Influence of spiritual characteristics of intelligence, emotional intelligence and personality type towards the attitude of the post-transformation of Stain Jurai Siwo Metro become Iain Metro
}

Buyung Syukron' ${ }^{1,}$ Dwi Vita Lestari ${ }^{2}$

\author{
${ }^{1}$ IAIN Metro, Lampung, Indonesia \\ ${ }^{2}$ STAIN Sultan Adurrahman. Kepulauan Riau, Indonesia \\ buyung.syukron@metrouniv.ac.id
}

Submitted : 30-08-2020, Revised : 24-09-2020, Accepted : 28-11-2020

\begin{abstract}
One of the important dimensions and aspects that are the key to addressing the needs of the role and function of democracy is to seek change or transformation of forms, systems and institutional structures. The purpose of this study was to determine the characteristics of the respondent (lecturer) which correlated with the type of Spiritual Intelligence, Emotional Intelligence and the type of personality possessed by perceptual lecturers in the transformation process of STAIN Jurai Siwo Metro into IAIN Metro. This type of research is quantitative. The nature of the research emphasizes numerical data (numbers) processed by statistical methods. While the research approach is carried out by describing the ex post facto. For data processing techniques using validity and reliability tests using the product-moment formula. The data analysis used in this research is the univariate analysis test, multivariate analysis test, classical assumption test, hypothesis test, and direct and indirect effect test. The results showed that the attitude of the lecturers influenced the transformation of STAIN Jurai Siwo Metro into IAIN Metro. The attitude of the lecturer towards the post-transformation process of STAIN Jurai Siwo Metro into IAIN Metro is a conflicting dysfunctional behaviour, covering several interconnected aspects, namely cognitive, affection, and behaviour which are influenced by various factors.

Keywords: Attitude Transformation; Emotional Intelligence; Personality Type; Spiritual Intelligence
\end{abstract}

\section{Introduction}

The change of status from STAIN Jurai Siwo Metro to IAIN Metro is based on Regulation No. 71 of 2017 will certainly lead to attitudes (individual reactions) with varying levels of support. There are individuals who with full awareness and sincerity participate fully in the occurrence of this change so that there are individuals who ignore / antipathy to the change in status to IAIN Metro at this time. These reactions or attitudes can be broadly mapped into two, namely between individuals who react positively (support) transformation and individuals who are not reactive (do not support) transformation. The process of change and reaction should be understood as an effort to get a concrete picture of readiness in carrying out Tridharma Perguruan Tinggi activities after the changes have occurred. This readiness is not only needed by the organization (in this case IAIN Metro), but also by its human resources, in this case, the lecturers. Because human attitudes and reactions to change contribute to the effectiveness of change itself, both for individuals and organizations (Rofiq, 2019). In the context and perspective above, this is the importance of IAIN Metro to position the tradition of spiritual intelligence, emotional intelligence, and personality types owned by this institution as a force that can provide a strong colour and influence on the transformation process that has occurred.

Spiritual intelligence is the intelligence of the soul that helps heal and build a whole human being; spiritual intelligence is the intelligence to deal with and solve problems of meaning and value. (Mahmood, Arshad, Ahmed, Akhtar, \& Khan, 2018). A well-developed spiritual intelligence will be characterized by a person's ability to be flexible, easy to adapt to the environment, to have a high level of awareness, to be able to face suffering, pain, and to be able to realize life by the vision and mission (Sisk, 2016). A study says that spiritual 
intelligence represents a longing for meaning and infinite relationships (Pant \& Srivastava, 2019). Supported by research which says that spiritual intelligence is related to being part of the design of everything bigger includes seeing a picture as a whole(Vasconcelos, 2020). Having spiritual intelligence allows us to bridge or unite personal and interpersonal things between ourselves and others because we will be aware of the integrity of others and our integrity and it is essential to build a good attitude towards change. A study says that spiritual intelligence can benefit us because spiritual intelligence can be used in crisis problems which make us seem to lose our self-order. Still, with spiritual intelligence, our conscience will lead to a more righteous path (Koražija, Žižek, \& Mumel, 2016). Furthermore, spiritual intelligence will be better if it is accompanied by good emotional intelligence because emotional intelligence is the ability to interpret, understand and manage the emotions of oneself and the people around them (Petrides et al., 2016), if spiritual intelligence and emotional intelligence can be well balanced, an individual will have self-regulating selfawareness, motivation.

A study says that having emotional intelligence at work reduces burnout and transmits enthusiasm and optimism (Aqqad, Obeidat, Tarhini, \& Masa'deh, 2019). Furthermore, emotional intelligence will affect self-empathy towards the environment. A study says that empathy is needed for someone to improve performance in an agency or job (Pekaar, van der Linden, Bakker, \& Born, 2017). Some of this intelligence affect personality types. Emotional intelligence makes a person more deeply in doing and behaving. Besides, religion and moral values will control human life and into personal development which, if firmly planted, will have a stronger influence in controlling behaviour and in shaping attitudes. Ability to face and solve problems of meaning and value, namely intelligence to place behaviour and life in a broader and richer context of meaning. Spiritual intelligence makes human beings who are truly intellectually, emotionally and spiritually, and can bridge themselves and others (Krisnanda \& Surya, 2019). This is because spiritual intelligence makes humans understand more about who they are, the meaning of everything for themselves, how they can give a place to themselves or other people.

The two bits of intelligence are actually related to one another, spiritual intelligence guides and influences emotional intelligence, thus making everything work synergistically. Suppose it is related to changes in the workspace, of course with the hope that after the transformation of the institutional form, it will not be difficult to adjust the systems, structures and processes that arise from the institutional change itself. This hope is a habit that is formed, which eventually forms the culture of IAIN Metro (IAIN Metro culture). Of course, what is meant by IAIN Metro culture is the pattern of spiritual intelligence, emotional intelligence, and personality types of IAIN Metro lecturers in the process of transforming the institutional form into a compatible format.

\section{Methods}

This type of research is a survey. The distinctive feature of this research is that it is always associated with a controllable system. This means that the author has a role in regulating the system under study, the author follows events that occur in real life, and the study is a closed system. The data analysis techniques used in this study were: univariate analysis and multivariate analysis. In this study, the application of multiple regression is carried out by considering several things: The sample is taken randomly from the normal population, the dependent variable data is the scale interval or scale ratio, the independent variable with the dependent variable has a theoretical relationship, and through simple 
correlation calculations, the significance of this relationship can be tested. The basis for this multivariate testing decision making is based on the $95 \%$ significance level (P-value). If the sig $\mathrm{P}$-value $<0.05$, then the hypothesis is rejected. If the sig $\mathrm{p}$ value $>0.05$, the hypothesis is accepted. To see whether there is multicollinearity or not, it is done by looking at the tolerance value and the opposite variant inflation factor (VIF). If the VIF Indigo $<10$ and the tolerance value $>0.1$, then there is no multicollinearity between the independent variables. To test this assumption is done using analysis with plot graphs. If the dots randomly spread either above or below zero on the y-axis, heteroscedasticity does not occur.

\section{Results and Discussion}

In this first regression test will see how much of each variable $\mathrm{X} 1, \mathrm{X} 2$, and $\mathrm{X} 3$ are, both partially and simultaneously. The partial correlation value of each free variable between $\mathrm{X} 1, \mathrm{X} 2$, and $\mathrm{X} 3$, can be seen in table 1 .

Table 1. The partial correlation

\begin{tabular}{ccccccc}
\hline Model & $\begin{array}{c}\text { Sum of } \\
\text { Squares }\end{array}$ & Df & $\begin{array}{c}\text { Mean } \\
\text { Square }\end{array}$ & F & Sig. & R Square \\
\hline Regression & 20.239 & 2 & 10.119 &, 382 &, $685^{\text {b }}$ &, 020 \\
\hline Residual & 979.661 & 37 & 26.477 & & & \\
\hline Total & 999.900 & 39 & & & & \\
\hline
\end{tabular}

From the table above it looks that the value R square 0.020 , it shows that only $2 \%$ of the $\mathrm{Y}$ variance (Faculty attitude) can be explained by the changes in the variable $\mathrm{X} 1$, (spiritual Intelligence), X2 (Emotional Intelligence), and X3 (personality type). It can also be interpreted that another factor of $98 \%$ influences the attitude variables.

To see if the contributions/influences of the X1, (spiritual Intelligence), X2 (Emotional Intelligence), and X3 (personality type) jointly influence significantly towards $\mathrm{Y}$, then the coefficiencies of the correlation test regression $\mathrm{F}$ or in other words $\mathrm{F}$ test is intended to test whether independent variables jointly influence significantly against dependent variables. With the hypothesis, that H0: Independent variables together have no significant effect on the dependent variables. The H1: Independent variables together have a significant effect on the dependent variables. As the basis of decision making is: if probability (sig value) $>0.05$ or $\mathrm{F}$ count $<\mathrm{F}$ table, then $\mathrm{H} 0$ is accepted. And if probability (sig value) $<0.05$ or F count $>$ Ftabel then $\mathrm{H} 0$ is rejected.

In the table above, the value of sig $=0.685>0.05$, so $\mathrm{H} 0$ is rejected, which means that the independent variables together have a significant effect on the dependent variables. It can be interpreted that if X1, (spiritual Intelligence), X2 (Emotional Intelligence), and X3 (personality type) together positively, then the attitude will be positive.

To see if the contributions/influences of the X1, (spiritual Intelligence), X2 (Emotional Intelligence), and X3 (personality type) are partially influential on the $\mathrm{Y}$, then the correlation coefficient of regression in the T-test or test is intended to test whether independent variables on a partial effect are significant to the dependent variable. Recapitulation of regression can be seen in figure 1 . 
Figure.1 Recapitulation of regression analysis results $(\mathrm{X} 1, \mathrm{X} 2, \mathrm{X3}$, and $\mathrm{Y})$

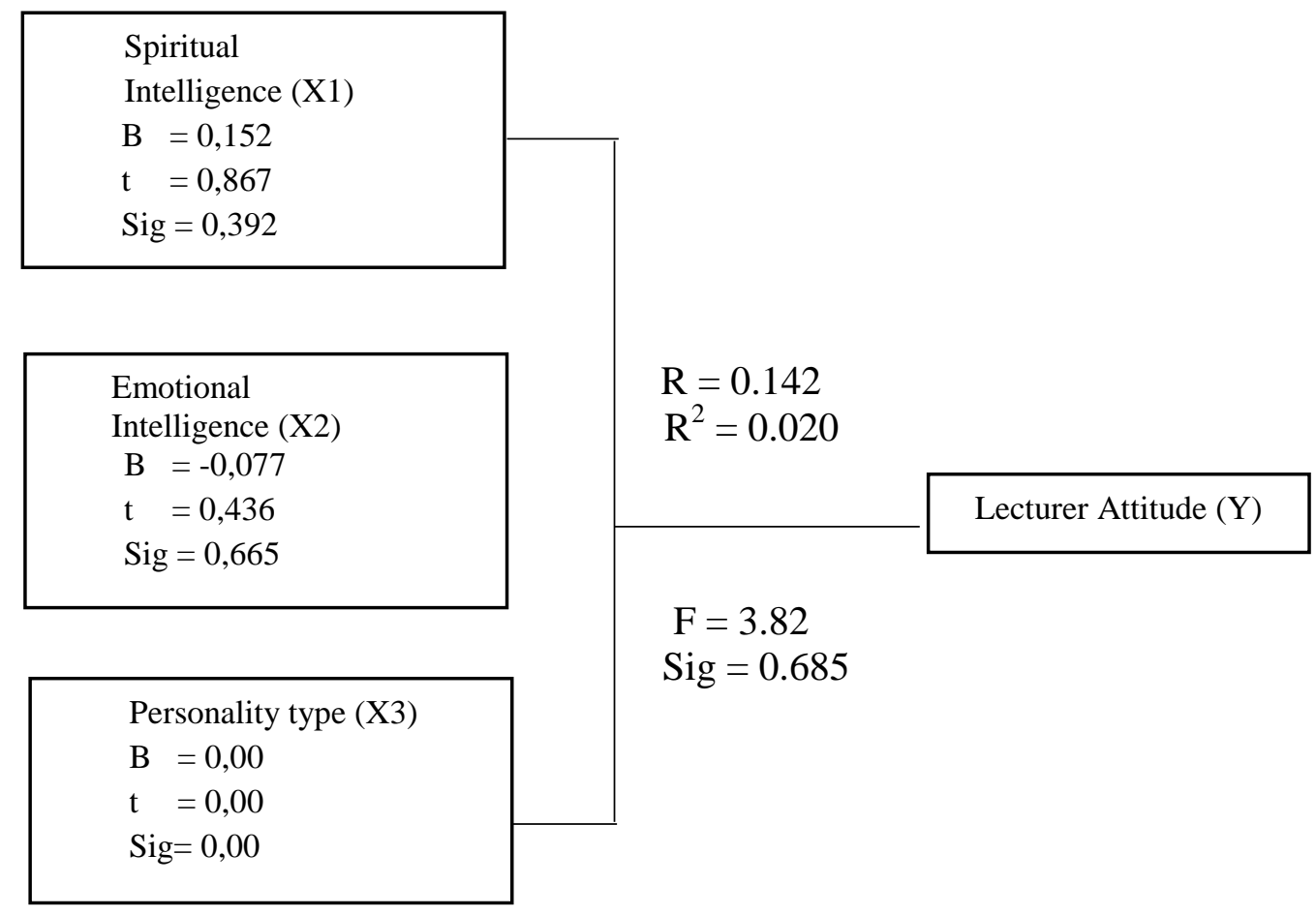

In this second regression test, it will be seen how much influence the variable $\mathrm{X} 1$ (Spiritual Intelligence), variable X2 (Emotional Intelligence), variable X3 (personality type) on variable Y (lecturer attitude), either partially or simultaneously. The value of the partial correlation of each independent variable between X1, X2, X3, against Y can be seen in table 2.

Table 2. The partial correlation

\begin{tabular}{ccccccc}
\hline Model & $\begin{array}{c}\text { Sum of } \\
\text { Squares }\end{array}$ & Df & $\begin{array}{c}\text { Mean } \\
\text { Square }\end{array}$ & F & Sig. & R Square \\
\hline Regression & 63,615 & 3 & 21,205 & 2,007 &, $130^{\mathrm{b}}$ &, 143 \\
\hline Residual & 380,360 & 36 & 10,566 & & & \\
\hline Total & 443,975 & 39 & & & & \\
\hline
\end{tabular}

From the table 2, it appears that the value of $\mathrm{R}$ Square is 0.143 , it shows that only $14.3 \%$ of the $\mathrm{Y}$ variance (lecturer attitude) can be explained by changes in variables (Spiritual Intelligence), variable X2 (Emotional Intelligence), variable X3 (personality type) to variable $\mathrm{Y}$ (lecturer attitude). And it can also be interpreted that another factor of $85.7 \%$ influences the lecturer's attitude variables. To see if the Contributions/influences of X1, X2, X3, jointly significantly affect the $\mathrm{Y}$, then the correlation coefficient of regression test is tested $\mathrm{F}$, or in other words, F tests are intended to test whether independent variables jointly withhold significantly against the dependent variable. With the hypothesis test, the H0: independent variables together have no significant effect on the dependent variables. The H1: Independent variables together have a significant effect on the dependent variables. As the basis of decision making is: if probability (sig value) $>0.05$ or $\mathrm{F}$ count $<\mathrm{F}$ table, then $\mathrm{H} 0$ is accepted. And if probability (sig value) $<0.05$ or $\mathrm{F}$ count $>\mathrm{F}$ tabel then $\mathrm{H} 0$ is rejected. In the table above, the value of sig $=0130>0.05$, so that $\mathrm{H} 0$ is rejected, which means the simultaneous independent variables have a significant effect on the dependent variables. It can be interpreted that if $\mathrm{X} 1$, (spiritual Intelligence), $\mathrm{X} 2$ (Emotional Intelligence), and $\mathrm{X} 3$ 
(personality type) together positively, then the attitude of the lecturer will also be positive. Results of multiple regression analysis (X1, X2, X3, and Y) can be seen in figure 2.

Figure 2. Results of multiple regression analysis (X1, X2, X3, and $Y)$

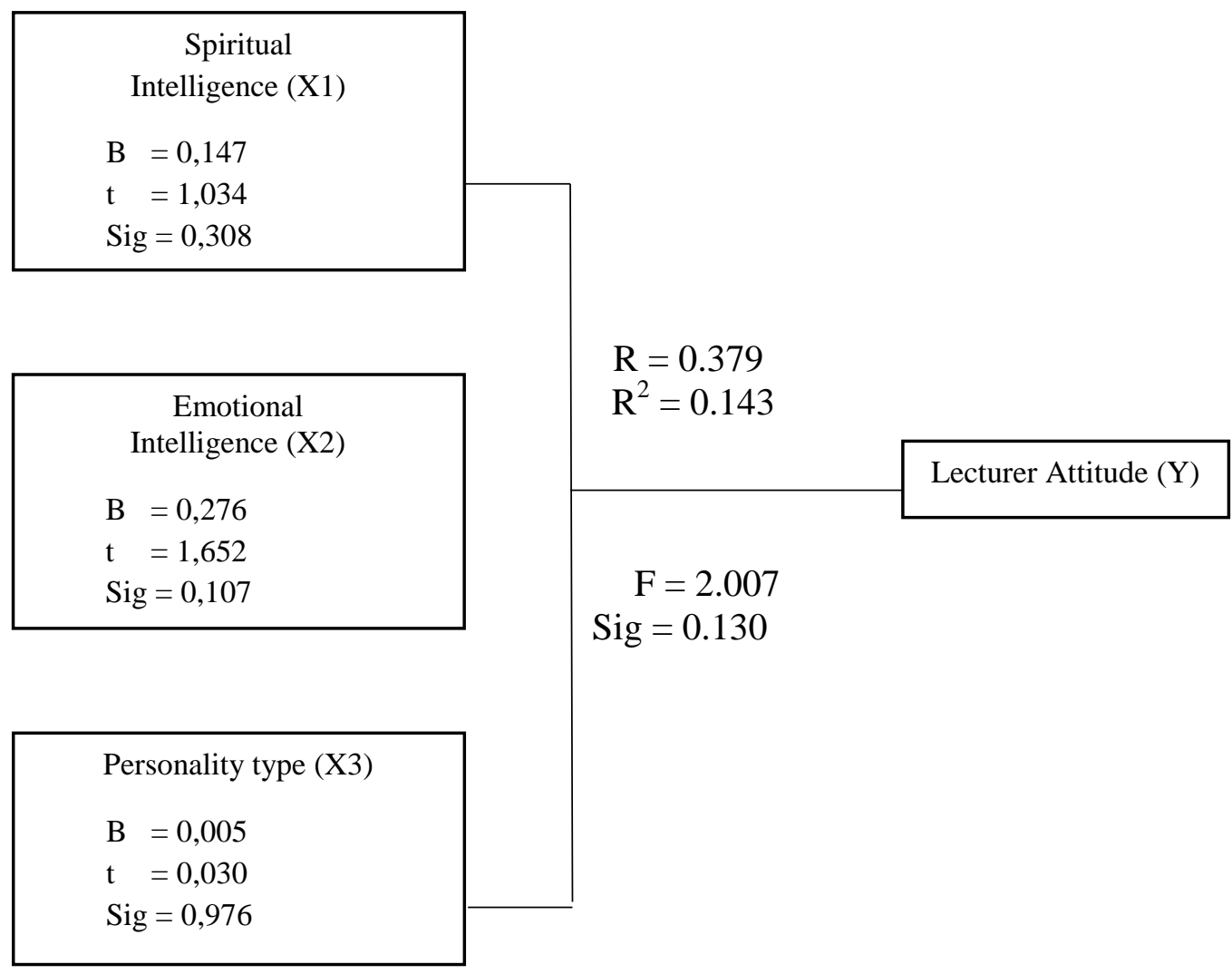

The first step in the analysis path is to calculate the path coefficients obtained from the value standardized regression coefficient or beta in the discussion of multiple regression $\mathrm{X} 1, \mathrm{X} 2, \mathrm{X} 3$, and $\mathrm{Y}$. The beta value is in the coefficient table with the result of the effect of the effects as follows.

1) Direct Effect

$$
\begin{array}{ll}
\mathrm{X}_{1} \rightarrow \mathrm{Y} & =0.152 \\
\mathrm{X}_{2} \rightarrow \mathrm{Y} & =-0.077 \\
\mathrm{X}_{3} \rightarrow \mathrm{Y} & =-0.113
\end{array}
$$

2) Indirect effects Effect of $X 1$ on $Y$

$$
\begin{array}{lll}
\mathrm{X}_{1} \rightarrow \mathrm{Y}: 0.152 \times-0.005 & =-0.001 \\
\mathrm{X}_{2} \rightarrow \mathrm{Y}:-0.077 \mathrm{x}-0.005 & =0.000 \\
\mathrm{X}_{3} \rightarrow \mathrm{Y}:-0.077 \mathrm{x}-0.005 & =0.000
\end{array}
$$

3) Total Effect

The effect of $\mathrm{X} 1$ to is the summation of direct influence $(\mathrm{X} 1 \rightarrow \mathrm{Y})$ and indirect influence $(\mathrm{X} 1 \rightarrow \mathrm{Y})=-0113+-0.001=-0114$.

The influence of $\mathrm{X} 2$ on $\mathrm{Y}$ is the summation of direct influence $(\mathrm{X} 2 \rightarrow \mathrm{Y})$ and indirect influence $(\mathrm{X} 2 \rightarrow \mathrm{Y})=(-0112)+(0.005)=(-0112)$

The influence of $\mathrm{X} 3$ toward $\mathrm{Y}$ is the summation of direct influence $(\mathrm{X} 2 \rightarrow \mathrm{Y})$ and indirect influence $(\mathrm{X} 3 \rightarrow \mathrm{Y})=(-0112)+(0.005)=(-0112)$ 
The result of this analysis path can be seen in figure 3 .

Figure 3. Recapitulation of line Analysis results

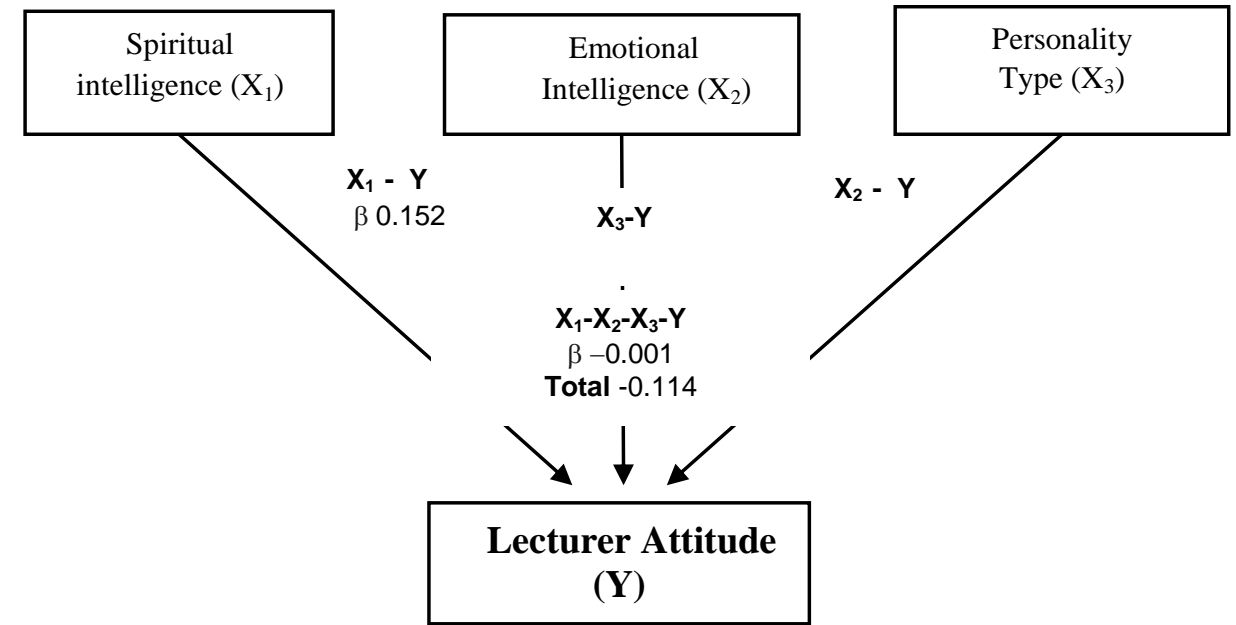

In this study, to see the relationship between spiritual intelligence, the emotional intelligence of the personality type, gained that the personality type was only $2 \%$ influenced by both variables together. It can also be interpreted that another factor of $98 \%$ influences a personality type variable. The more important factors that influence personality development are two main factors, namely hereditary factors (genetics) and environmental factors (environment). Genetic factors (innate), at the time of conception, the entire congenital hereditary individual is formed from 23 chromosomes of the mother, and 23 chromosomes of the father. In 46 chromosomes, there are thousands of genes containing individual physical and psychic properties or that determine their hereditary potential. In this case, no one can increase or decrease the potential of the hereditary. The influence of genes on personality, in fact, not directly because that is influenced by genes indirectly is (1) The quality of the nervous system, (2) The biochemical balance of the body, and (3) The structure of the body. Further, it can be argued that a hereditary function about personality development is (1) as a source of raw material personality such as physical, intelligence, and temperament (2) limiting personality development and influencing personality uniqueness.

Individual abilities and adaptations are limited by the traits inherent in the individual organism itself (Marsh, 2020). For example, physical capacity (stature, energy, strength, and honesty), and intellectual capacity (intelligent, normal, or retarded). However, the limitations of personality development are, however large, influenced by environmental factors. It can be concluded that heredity greatly affects the "self-concept" of an individual as the basis for individuality so that no one has the same personality pattern even though they are identical twins (Nurnberger Jr et al., 2018).

The temperament dimensions: emotionality, activity, aggressiveness and reactivity of the seed plasma (genes) are cases of intelligence (Shilton, Breski, Dor, \& Jablonka, 2020). A study says that genius is closely related to family (Goshen-Gottstein, 2017). This finding is evidence that supports a hereditary theory of individual genius. A study of twins; has examined the hereditary contributions to height and weight, intelligence and personality. They put 19 pairs of identical twins under separate rearing, 50 pairs of identical twins under the same rearing, and 50 pairs of "fraternal" twins under the same rearing as well. The results show that identical twins are separated from each other in their height and weight, as well as in their intelligence (Schmitt, Raznahan, Liu, \& Neale, 2020). Likewise, identical twins stay together, seeming to have more in common than "fraternal" twins. Diversity of body (posture) 
of constitutionality; Hippocrates believed that human temperament could be explained in terms of fluids. Kretschmer has classified individual postures into three main types, and one mixed type. This classification is based on his research on 260 people he fosters. The following are the types of body classifications, according to Kretschmer. 1) Picnic type (Stenis): short, fat, big belly, round chest and shoulders, 2) Asthenis type (Leptoshom): tall and slender, small stomach, and narrow shoulders, 3) athletic type: harmonious posture (straight, shoulders) wide, a strong stomach, strong muscles), 4) dysplastic type: a type of deviation from the three forms above.

These types are associated with (1) Mental disorders, such as the type of Piknis associated with manic depression, and Astenis. (2) Characteristics of normal individuals, such as the picnic type, are friendly and calm, while Asthenis is serious, calm and likes to be alone. Environmental factors that influence personality include family, culture, and school. Family is seen as the main determinant in shaping the child's personality. The reasons are (1) the family is the first social group to become the Child Identification Center, (2) Many children spend their time in the family environment, and (3) family members are "important people" for shaping the child's personality. A study found that children who thrive in a democratic climate tend to have personality traits: more active, more social, more selfconfident, and more constructive than children who grow up in an authoritarian climate (Leipoldt, Harder, Kayed, Grietens, \& Rimehaug, 2019). Furthermore, other research says cultural factors influence us to follow certain patterns of behaviour that other people make for us (Fernández-Gómez et al., 2020)

The independent variable X1 partially influences and is significant on variable Y. At the same time, X2 and X3 partially do not have a significant effect on variable $\mathrm{Y}$. Independent variable $\mathrm{X} 1$ partially and significantly influences variable $\mathrm{Y}$, a person's personality can be influenced by spiritual intelligence because of the characteristics of people who spiritually intelligent, namely: 1) the ability to penetrate physically and materially; 2) The ability to experience a level of consciousness that has reached its peak; 3) Ability to normalize daily experiences; 4) Ability to use spiritual resources to solve problems, and 5) Ability to do good.

These five intelligent, spiritual characteristics will accumulate in a person's personality, so the higher a person's spiritual intelligence, the better his personality will be. However, partially X2 does not have a significant effect on variable $\mathrm{Y}$, this is because the emotional intelligence of students has an average emotional intelligence so that the average limit of this emotional intelligence does not affect a person's personality.

In the theory of emotional intelligence put forward by Goleman, two factors can affect a person's emotional development, namely the maturity factor and the learning factor (Goleman, 2001).

Maturity factor, namely the result of intellectual development in the ability to understand the meaning that was not previously understood, paying attention to a stimulus over a longer period of time and determining the emotional tension of an object. The ability to remember and suspect affects emotional reactions so that children become reactive, which initially does not affect him. The development of the endocrine glands is important for developing emotional attitudes. The adrenal glands play a major role in emotions, and this role develops rapidly at the age of 5-11 years. These glands will grow back until the age of 16 years. These factors can be controlled by maintaining physical health and body balance, namely through controlling the glands whose secrecy is driven by emotion. 
The study factor is more manageable; the way of controlling the environment to ensure the development of the desired emotional pattern and eliminating unwanted emotional reaction patterns is a pattern of positive assessment and preventive action. The older they are, the harder it is to change reaction patterns. There are five types of learning activities that contribute to patterns of emotional development, namely learning by imitating Learning, learning by imitating, learning by identifying, learning by conditioning, and training.

The parenting factor, this factor determines the certainty of a person's emotional memory, because many of the strong emotional memories come from the first years of life, in the pattern of relationships between babies and their carers, especially applies to traumatic events, such as beatings or survivors. During the early period of life, the brain structure that is responsible for storing all forms of emotion, the amygdala develops very rapidly in the baby's brain, even almost fully formed at birth, while other brain structures, especially the hippocampus, where rational thinking has not yet developed. Has been fully developed.

Cultural factors, in this case, culture is the value or structure of the theoretical structure that applies in society, thus determining one's attitudes and behaviour because they have to deal with 32 other members of society. Furthermore, social patterns in society determine the colour of a person's personality because a person experiences growth and development in society.

Emotional intelligence in someone who has emotional intelligence on average can be caused by two factors, namely the maturity factor and the learning factor. Maturity factor in early semester students is the limit of early adolescence, indicating that maturity in adolescence is in the process of emphasizing the quality of development or in other words, it has not reached maturity. Meanwhile, learning factors on students' emotional intelligence do not have much learning experience in their life span, because at this age limit adolescents still prioritize parents in dealing with problems so that the average emotional intelligence of these students does not affect-student personality.

From these data it can be seen that only $14.3 \%$ of the $\mathrm{Y}$ variant (lecturer attitude) can be explained by changes in the variables X1 (spiritual intelligence), X2 (Emotional Intelligence), and X3 (personality type), and. It can also be interpreted that other factors equal to $85.7 \%$ affect the attitude variable. This is because in this study the spiritual variables, namely Intelligence, Emotional Intelligence, and Personality Type have an average value, and for the personality type it is a closed personality type so that these three variables greatly affect the attitude of the lecturer. Partial and simultaneous independent variables do not have a significant effect on the dependent variable. This means that if spiritual intelligence, emotional intelligence, and personality types are improved separately or together, it will not affect the lecturers' attitudes towards the IAIN transformation process that has been experienced by IAIN Metro. The attitude of the lecturer towards the post-transformation process of STAIN Jurai Siwo Metro into IAIN Metro is a conflicting dysfunctional behaviour, covering several interrelated aspects, namely cognitive, affection, and behaviour which are influenced by various factors. The causes and dynamics of attitudes that occur also vary greatly between one task and the same task for the same person.

In general, experts distinguish the factors that influence this attitude into internal factors and external factors. Internal factors found in individuals include physical and psychological conditions. Like someone who is experiencing fatigue, his condition tends to make it easier to make attitude changes. A study says fatigue can be a reason to postpone doing or doing something because if you work in a tired condition, it will result in 
insufficient work done (Gore, 2018). Psychological conditions refer to individual personality traits. Strengthened by research that states personality traits affect attitudes, including selfefficacy and locus control, where individuals have lower self-efficacy and locus of external control, tend to be higher in seeing a process of institutional change (transformation) (Rosique-Blasco, Madrid-Guijarro, \& García-Pérez-de-Lema, 2018). In this study, the average lecturer has a closed personality which can lead to higher attitudes in seeing the process of change.

\section{Conclusions and Suggestions}

From the results of the study it can be concluded that Spiritual Intelligence, Emotional Intelligence, and Personality Type have average values, and for personality type is a closed personality type so that these three variables greatly influence the attitudes of lecturers. The attitude of the lecturer towards the post-transformation process of STAIN Jurai Siwo Metro into IAIN Metro is a conflicting dysfunctional behaviour, covering several interconnected aspects, namely cognitive, affection, and behaviour which are influenced by various factors. The causes and dynamics of attitudes that occur also vary greatly between one task and the same task for the same person. Further researchers are advised to provide treatment to improve spiritual intelligence and emotional intelligence

\section{References}

Aqqad, N., Obeidat, B., Tarhini, A., \& Masa'deh, R. (2019). The relationship among emotional intelligence, conflict management styles, and job performance in Jordanian banks. International Journal of Human Resources Development and Management, 19(3), 225-265.

Fernández-Gómez, E., Luque-Vara, T., Moya-Fernández, P. J., López-Olivares, M., Gallardo-Vigil, M. Á., \& Enrique-Mirón, C. (2020). Factors Influencing dietary patterns during pregnancy in a culturally diverse society. Nutrients, 12(11), 3242.

Goleman, D. (2001). Emotional intelligence: Issues in paradigm building. The Emotionally Intelligent Workplace, 13, 26.

Gore, B. F. (2018). Workload and fatigue. In Space Safety and Human Performance (pp. 5385). Elsevier.

Goshen-Gottstein, A. (2017). The Model: Developing a methodology for studying (religious genius). In Religious Genius (pp. 43-66). Springer.

Koražija, M., Žižek, S. Š., \& Mumel, D. (2016). The relationship between spiritual intelligence and work satisfaction among leaders and employees. Naše Gospodarstvo/Our Economy, 62(2), 51-60.

Krisnanda, P. H., \& Surya, I. B. K. (2019). Effect of emotional and spiritual intelligence on transformational leadership and impact on employee performance. International Research Journal of Management, IT and Social Sciences, 6(3), 70-82.

Leipoldt, J. D., Harder, A. T., Kayed, N. S., Grietens, H., \& Rimehaug, T. (2019). Determinants and outcomes of social climate in therapeutic residential youth care: A systematic review. Children and Youth Services Review, 99, 429-440.

Mahmood, A., Arshad, M. A., Ahmed, A., Akhtar, S., \& Khan, S. (2018). Spiritual 
intelligence research within human resource development: A thematic review. Management Research Review.

Marsh, T. (2020). Within-Species individual differences. The Sage Handbook of Evolutionary Psychology: Foundations of Evolutionary Psychology, 379.

Nurnberger Jr, J. I., Austin, J., Berrettini, W. H., Besterman, A. D., DeLisi, L. E., Grice, D. E., ... Ross, D. A. (2018). What should a psychiatrist know about genetics?: review and recommendations from the residency education committee of the international society of psychiatric genetics. The Journal of Clinical Psychiatry, 80(1).

Pant, N., \& Srivastava, S. K. (2019). The impact of spiritual intelligence, gender and educational background on mental health among college students. Journal of Religion and Health, 58(1), 87-108.

Pekaar, K. A., van der Linden, D., Bakker, A. B., \& Born, M. P. (2017). Emotional intelligence and job performance: The role of enactment and focus on others' emotions. Human Performance, 30(2-3), 135-153.

Petrides, K. V, Mikolajczak, M., Mavroveli, S., Sanchez-Ruiz, M.-J., Furnham, A., \& PérezGonzález, J.-C. (2016). Developments in trait emotional intelligence research. Emotion Review, 8(4), 335-341.

Rofiq, C. (2019). Kepemimpinan transformasional dalam lembaga pendidikan madrasah. Jurnal Penelitian Agama, 20(2), 203-226.

Rosique-Blasco, M., Madrid-Guijarro, A., \& García-Pérez-de-Lema, D. (2018). The effects of personal abilities and self-efficacy on entrepreneurial intentions. International Entrepreneurship and Management Journal, 14(4), 1025-1052.

Schmitt, J. E., Raznahan, A., Liu, S., \& Neale, M. C. (2020). The genetics of cortical myelination in young adults and its relationships to cerebral surface area, cortical thickness, and intelligence: A magnetic resonance imaging study of twins and families. NeuroImage, 206, 116319.

Shilton, D., Breski, M., Dor, D., \& Jablonka, E. (2020). Human social evolution: Selfdomestication or self-control? Frontiers in Psychology, 11, 134.

Sisk, D. A. (2016). Spiritual intelligence: Developing higher consciousness revisited. Gifted Education International, 32(3), 194-208.

Vasconcelos, A. F. (2020). Spiritual intelligence: A theoretical synthesis and work-life potential linkages. International Journal of Organizational Analysis. 